\title{
Contradictions between and within school and university activity systems helping to explain students' difficulty with advanced mathematics
}

DOI:

10.1093/teamat/hrw014

\section{Document Version}

Accepted author manuscript

Link to publication record in Manchester Research Explorer

Citation for published version (APA):

Jooganah, K., \& Williams, J. S. (2016). Contradictions between and within school and university activity systems helping to explain students' difficulty with advanced mathematics. Teaching Mathematics and its Applications, 35(3), 159-171. https://doi.org/10.1093/teamat/hrw014

\section{Published in:}

Teaching Mathematics and its Applications

\section{Citing this paper}

Please note that where the full-text provided on Manchester Research Explorer is the Author Accepted Manuscript or Proof version this may differ from the final Published version. If citing, it is advised that you check and use the publisher's definitive version.

\section{General rights}

Copyright and moral rights for the publications made accessible in the Research Explorer are retained by the authors and/or other copyright owners and it is a condition of accessing publications that users recognise and abide by the legal requirements associated with these rights.

\section{Takedown policy}

If you believe that this document breaches copyright please refer to the University of Manchester's Takedown Procedures [http://man.ac.uk/04Y6Bo] or contact uml.scholarlycommunications@manchester.ac.uk providing relevant details, so we can investigate your claim.

\section{OPEN ACCESS}




\section{OXFORD | Teaching Mathematics and Its Applications:}

\section{International Journal of the IMA}

\section{Contradictions between and within School and University Activity Systems helping to explain students' difficulty with Advanced Mathematics}

\begin{tabular}{|r|l|}
\hline Journal: & $\begin{array}{l}\text { Teaching Mathematics and Its Applications: International Journal of the } \\
\text { IMA }\end{array}$ \\
\hline Manuscript ID & TEAMAT-2015-093.R2 \\
\hline Manuscript Type: & Original Article (Section A) \\
\hline Date Submitted by the Author: & 08-May-2016 \\
\hline Complete List of Authors: & $\begin{array}{l}\text { Jooganah, Kamilah; Nottingham Trent University, Centre for Academic } \\
\text { Development and Quality } \\
\text { Williams, Julian; MIE, SEED University of Mancs }\end{array}$ \\
\hline Keywords: & $\begin{array}{l}\text { advanced mathematics, activity theory, contradictions, cognitive conflict, } \\
\text { advanced mathematics; activity theory; contradictions; cognitive conflict }\end{array}$ \\
\hline &
\end{tabular}

\section{SCHOLARONE"}

Manuscripts 
Kamilah Jooganah

Dr Kamilah Jooganah is currently working in the Centre for Academic Development and Quality at Nottingham Trent University. Prior to this, she worked on the TransMaths research project funded by the Economic \& Social Research Council that investigated student transition into mathematically demanding subjects in higher education. This project involved working with a number of case study higher education institutions. Kamilah completed her PhD at the University of Manchester where she researched undergraduate student experiences with Advanced Mathematics. Her background is in Social Anthropology.

Julian Scott Williams

Julian Williams is Professor of Mathematics Education at The University of Manchester, where he led a series of ESRC-funded "Transmaths" (www.transmaths.org) research projects that investigated mathematics education in the post-compulsory transitions from school to university. He has a longstanding interest in curriculum, pedagogy and assessment in mathematics and across STEM, in mathematical modelling, and in links with vocational and outside-school mathematics. This work has led to interests in social theory and the political economy of education. 


\title{
Contradictions between and within School and University Activity Systems helping to explain students' difficulty with Advanced Mathematics
}

\author{
K. JOOGANAH \\ Centre for Academic Development and Quality, Nottingham Trent University, Dryden Centre, \\ Dryden Street, Nottingham, NG1 4BU, UK \\ AND \\ J. S. WILLIAMS \\ School of Environment, Education and Development, Ellen Wilkinson Building, The \\ University of Manchester, Oxford Road, Manchester, M13 9PL, UK \\ $\$$ Corresponding author. Present address: Centre for Academic Development and Quality, \\ Nottingham Trent University, Dryden Centre, Dryden Street, Nottingham, NG1 4BU, UK \\ \$Corresponding author. Email: kamilah.jooganah@ntu.ac.uk
}

[Submitted May 2016]

This paper explores how contradictions, as framed by activity theory (Engeström, 1987), can explain first year undergraduate students' experiences of learning advanced mathematics. Analysing qualitative interview and observational data of students and lecturers based in one university mathematics department, we argue that contradictions between the school and university activity systems, as well as those within the latter, help explain some of the difficulties, including the conflict in cognition and identity, students can experience when they encounter advanced mathematics at university. This helps us to adopt a critical stance towards the systems students are expected to learn in, and points to system developments that might better support student learning.

Keywords: advanced mathematics; activity theory; contradictions; cognitive conflict

\section{Introduction}

When students enter university they may experience significant challenges in understanding advanced mathematics, especially marked by proof, rigour and precision. This raises serious concerns about students' transition to Advanced Mathematical Thinking (AMT), that is, 'thinking that requires deductive and rigorous reasoning about mathematical notions that are not entirely accessible to us through our five senses' (Edwards et al., 2005, pp. 17-18).

There have been various approaches taken to students' experiences with learning advanced mathematics (only a selection of which are discussed here), each offering a different theoretical lens to conceptualise student difficulty. With the cognitive approach, students are often presented as lacking certain mental abilities, or simply being ill-prepared to conceptually engage with advanced mathematics (e.g. Duval, 2006; Tall, 2008; Thomas \& Stewart, 2011). This literature can reduce student difficulty with advanced mathematics to student cognitive processes, and where the sociocultural is discussed, it is often presented as secondary to student cognition. There is research that takes a sociocultural approach, which frequently explains student learning in relation to mathematical communities (e.g. Hemmi, 
2008; Perrenet \& Taconis, 2009; Biza et al., 2014). These communities are considered to mediate students' learning and understanding of mathematics. In this paper we combine the sociocultural and cognitive dimensions of students' learning of advanced mathematics using activity theory (Engeström, 1987). From this perspective, the 'activity of learning' is essentially a social process in a collective 'activity system', i.e. an ensemble of social relations mediated by cultural artifacts and social norms. We will argue that the contradictions within and between the school and university activity systems can help to explain some of the difficulties students encounter with advanced mathematics, including conflicts to cognition and identity they may experience. In this way we aim to put the social and cultural in the middle of developing praxis, but also to socioculturally situate the cognitive perspective. In conclusion, we aim to offer a critical sociocultural 're-mediational' perspective that leads to suggestions for developing the learning systems themselves.

\section{Literature on advanced mathematical thinking at university}

The long history of cognitive-based literature suggests that students can experience difficulty with advanced mathematics for a number of reasons, including: challenges with the process of reflective abstraction (Dreyfus, 1991; Duval, 2006); challenges with abduction in proof construction, such as in making inferences (Pedemonte \& Reid, 2011); student confusion between natural language and mathematical registers (Mejía-Ramos \& Inglis, 2011); a lack of student familiarity with the mathematical notation needed for advanced mathematics (Moore, 1994); student difficulties with definitions (Ouvrier-Buffet, 2011); student issues with reading and identifying proof (Selden \& Selden, 2003; Yang, 2011); poor student judgement of what constitutes proof (Weber, 2010); a lack of ability to mentally compress mathematical structures into manageable cognitive units (Barnard, 2002; Harel \& Kaput, 1991); and particular subject specific barriers to conceptual understanding (Mahir, 2009). The research that adopts a cognitive perspective generally argues that students' experience challenges with AMT as they face the formidable task of cognitively engaging with mathematics in ways significantly different from that which they experienced previously, e.g. at school, inducing a classically Piagetian form of 'cognitive conflict' (Gray et al., 1999). This cognitive conflict is assumed to occur through a tension between accommodation and assimilation in student cognition (e.g. Edwards \& Ward, 2004; Gray et al., 1999; Tall, 1991; Tall, 2008; Thomas \& Stewart, 2011).

There is research that focuses more on the social aspects of student learning of mathematics at university. This body of literature has often drawn on the communities of practice model of learning (Lave \& Wenger, 1991; Wenger, 1998) to frame student learning as a process of enculturation into the practices of a mathematics community/communities (e.g. Hemmi, 2008; Perrenet \& Taconis, 2009; Biza et al., 2014). This process can be problematic as school mathematics often instil a mathematical repertoire that is misaligned with those held by professional or more experienced mathematicians, presumed to be the 'old timers' in the university community of practice (Perrenet \& Taconis, 2009). Moreover, studies indicate problems with the teaching of advanced mathematics at university that can hinder the process of student enculturation, such as where there is a lack of transparency in the teaching of proof, i.e. where it is not made explicit in lecturers' presentations, and where teaching lacks meaningful student-lecturer discussions about proof and proof technique (Hemmi, 2008; Biza et al., 2014). This can result in some students believing that proof production is an unattainable skill and something which only lecturers do and not students (Solomon, 2006).

For heuristic purposes (the literature is more nuanced), we can consider the research that takes a cognitive approach to frame learning as 'acquisition' via assimilation and accommodation 
whereas research that draws on the communities of practice model typically presents learning as 'participation' in practice. These different approaches can be characterised by 'acquisition metaphors' (AM) and 'participation metaphors' (PM) (Sfard, 1998) and have been argued to separately share much of the same conservative bias. Specifically, with the AM approach primary importance is often placed on concepts which are framed as empirical and formal (Engeström \& Sannino, 2010). By contrast, research that draws on the PM approach tends not to focus on psychology in general and the formation of theoretical concepts in particular, as researchers from this community of practice also tend to view concepts as formal abstractions (Engeström \& Sannino, 2010).

Activity theory - or Cultural-historical Activity Theory (ChAT) - invokes both the psychological and the sociocultural. Activity theory, after Vygotsky's legacy, frames concepts as arising in social practice (on the intermental plan) and transforming the psyche via the intramental plain (inner speech and verbal thought). It offers a perspective on how knowledge can be transferred across learning situations, but suggests that the process of knowledge transfer is not one that involves the movement of an isolated, intact conceptual entity divorced from the sociocultural environment (Engeström \& Sannino, 2010). Rather, conceptual knowledge is framed in such a way as to develop and evolve in practice where the process of transfer involves a change in knowledge and context (Engeström \& Sannino, 2010). Indeed, from the perspective of activity theory, concepts are embedded and distributed in and across activity systems as well as embodied in individuals. This perspective on how student cognitive activities, including the cognitive difficulties encountered, are socioculturally situated helps to offer a more holistic explanation regarding student experiences with AMT, since it promises to attach research on student's conceptual difficulties to the sociocultural practices in which they are situated.

\section{Activity systems and their contradictions}

Activity theory is a cross-disciplinary framework, a conceptual and descriptive tool for analysing and explaining human activity (Sannino et al., 2009). Activity theory is rooted in dialectical materialism, as developed by Marx and Engels: thus when humans (the subjects) perform labour activity (using tools) they not only transform nature (the object), but are transformed themselves in the process (Vygotsky, 1978). According to Vygotsky (1978, 1981), human consciousness is developed and shaped through joint activity with others mediated by cultural tools including 'language; various systems of counting; mnemonic techniques; algebraic symbols systems; works of art; writing; schemes, diagrams, maps and mechanical drawings; all sorts of conventional signs and so on' (Vygotsky, 1981, p. 137). Tools are products of sociocultural evolution, imbued with particular cultures and histories, and are produced and reproduced in human activity; thus tools can be conceptualised as carrying accumulated social knowledge that is transmitted with use (Leontiev, 1981). Tools are reasoned by Vygotsky to mediate activity and so are important to the development of higher cognitive functioning.

Engeström (1987) expands on Vygotsky's and Leontiev's ideas and advances that activity is situated in a larger community governed by rules and a division of labour which also mediate activity, regulating individual actions. Importantly, as Barab et al., (2002) state: 'The components of activity systems [subject, object, tools, community, rules and division of labour] are not static components existing in isolation from each other but are dynamic and continuously interact with the other components through which they define the activity system as a whole' (p.79). 
According to Engeström (2001, p. 137), activity systems always harbour contradictions. Contradictions, not to be confused with the vernacular or standard usage of the term, should be considered as 'historically accumulating structural tensions within and between activity systems'. Contradictions have also been referred to as a general misalignment within and between the components in an activity system, or between different activities (Kuutti, 1996).

Williams et al., (2001) provide insight into the difficulties students may encounter when moving from one activity system to another. One student in a lab placement struggled to understand how graphs are used in an industrial chemistry experiment. They explain the primary difficulty by the contradiction between workplace and school graphing activity and its mediating tools: the lab's graph was read from right to left, plotted more than one variable on each of the axes, used a logarithmic scale etc. Hence the student was equipped with tools from school that were misaligned with the tools needed in the lab. In this case the student's cognitive conflict - in their conscious actions - embodied the contradiction between the two systems.

This conflict in cognition from the perspective of activity theory can also be read as one related to the multi-voicedness of activity systems. According to Engeström (2001), activity systems are always comprised of a community of multiple perspectives, traditions and interests, where the participants carry their own diverse histories. The multi-voicedness of activity systems increases when they activity systems interact (Engeström, 2001) and we may imagine that this multi-voicedness can also manifest in different mathematical practices. Engeström suggests that the multi-voicedness of activity system can be a source of conflict. Thus, from the perspective of activity theory, cognitive conflict can be conceptualised as an interpersonal conflict, caused by the differences in mathematical practices, giving rise to conflict of an intrapersonal kind. Indeed, from the perspective of activity theory we cannot discuss the cognitive conflict students may experience without turning attention to the conflict in identity they can also encounter; cognition and identity are unified. As Nardi (1996) argues 'consciousness is not a set of discrete disembodied cognitive acts (decision making, classification, remembering), and certainly it is not in the brain; rather, consciousness is located in everyday practice: you are what you do' (p. 8).

In this paper we frame many of the difficulties students encounter with advanced mathematics, including the conflict to cognition and identity, as due to, or explained by, the contradictions between the school and university activity systems. This helps us to situate the literature that discusses students' difficulties with advanced mathematics, and with transition in general in the broader, complex sociocultural landscape of institutional activity systems (school and university). These activity systems, together with inherent tensions, are embodied in students and in some cases can challenge students' identification with mathematics.

Lawson (2015) describes how most undergraduate mathematics students believe they are good at mathematics and that their pre-university examination results appear to confirm this. However, when some students cease to find mathematics as straightforward as they found it at school, they face the realisation that their positive disposition towards mathematics was primarily grounded on the affirmative emotions generated by success at school rather than due to a deeper interest in the subject. In addition to the difficulties students encounter with mathematics at university, students can experience challenges with aspects associated with learning at university in general where new demands are made on them. For example, Pritchard (2015) argues that the familiar didactical contract at school, where teachers provide regular affirmation of students' performances and give them enough procedures to pass 
assessments, is threatened when they enter university, because of the greater emphasis placed on independent learning.

The challenges that students can experience in transition are noted elsewhere. Williams (2015) observes that lecturers tend to expect students to learn how to become independent learners and often expect students to have well developed advanced mathematical conceptions. However, he stresses that the teaching practices in universities are habitually transmissionist and they do not foster meaningful student-lecturer dialogue which in turn does not effectively develop students' conceptual understanding of mathematics or help to nurture the independent skills required for successful learning at university. As well as causing conflict, structural tensions within activity systems can also be a source of developmental change and promote individual learning when they result in 'breakdowns'.

\footnotetext{
'Breakdowns' occur when automatic or routine operations are disrupted, which can lead to a reassessment of these operations involved in activity (Leontiev, 1978). In our paper we report an occurrence of a breakdown and how this reveals potential for development which may be of use to universities when reflecting on their own practices in how to support student transition to AMT.
}

Biza et al., (2014) - drawing on the communities of practice framework as well as on the theory of communities of inquiry, based on the works of Goodchild et al., (2013) and others propose that developing communities of inquiry characterised by lecturer-student dialogue and questioning, or inquiry, around advanced mathematics can help to effectively support student learning when at university. They also suggest that inquiry can help lecturers to critically reflect on their teaching and adjust their practices accordingly. They argue that with the communities of inquiry approach, emphasis is placed on critical alignment where participants question the practices in which they engage, and that through this process it may be possible that this 'leads to new forms of practice, new modes of awareness of the problems and issues in developing effective ways of working, and good outcomes for students' learning' (p. 164). We argue that by addressing contradictions and thus facilitating breakdowns one can create such critical alignment.

\section{Methods}

The research reported here (doctoral work to be found in full in Jooganah, 2015) was conducted in association with the Transmaths project and included case study and interviews in one university mathematics department with the aim of understanding students' learning experiences of advanced mathematics (for more information on the Transmaths project, see http://transmaths.org/). There is no clear consensus on how activity theory should be applied, but, as Jonassen \& Rohrer-Murphy (1999) argue, because the theory focuses on cultural practice, a qualitative approach is generally taken (i.e. an approach where emphasis is generally placed on capturing the multi-dimensionality and complexity of participant experiences), e.g. in examining how cultural artifacts mediate social practice.

This paper draws on the semi-structured interviews conducted with eight first-year undergraduate mathematics students during the course of their first transitional year at university. They were asked general questions about their learning experiences at school and university, for example, 'What are the differences between school and university mathematics, and between teaching styles? What areas are you struggling with and why?' 
The paper is also informed by 12 unstructured interviews with lecturers. In this form, lecturers were able to discuss issues they felt were significant to students' learning experiences with advanced mathematics, with the additional benefit of yielding rich data that may have been lost within a more structured approach. For example, we used a videostimulated recall interview with a lecturer who we interviewed about one of his tutorials which we filmed (for which we obtained consent from him and his tutor group as part of our research). This interview involved us showing the lecturer the filmed tutorial and asking him general questions about what happened in the tutorial and what he felt was significant.

In addition, observations of the teaching environment that shape first-year students' learning were useful for constructing an informed assessment of the university activity system of the mathematics department. This included observing interactions in small group tutorials (7) and lectures (10). One of the tutorials observed is presented in this paper as a vignette.

\section{Findings: contradictions between school and university}

In the transition to university, students experience a number of academic changes, for which lecturers reportedly claimed students were 'not prepared'. We were informed that these problems required the mathematics department to adjust their academic programmes and a series of changes had occurred over a number of years in response to such disjunctures. One lecturer, Brian, (all participant names have been replaced with pseudonyms) commented in a manner that typically blames schools and their examination systems for the problems students encounter at university:

Brian: I think they've been poorly prepared by schools and by the examination system. They're really too much spoon-fed. And yet we don't spoon-feed them quite so much, although we do spoon-feed them more than we would have done, say twenty, thirty years ago because of awareness of what's happened previously. I suppose we expect them to study more on their own. I suspect they've had more, closer attention than from when they've been in schools and colleges - been helped more. Whereas here we'd expect them to attend lectures and do enough study. Do lecture notes, do the exercises, go to the tutorials, read books by themselves and be more responsible for their own learning. I wonder whether schools and colleges have done enough of that.

Brian indicates how students' subjective experiences of education at school stand in contrast with the learning culture at university. The lecturers generally contrasted the procedural approaches taken by students at school with the greater level of rigour and conceptual generality demanded by university approaches to mathematics. Martin put it thus: 'They get taught methods at school and then they come here and of course, shall we say, we do it properly, and the students will say 'why are you doing it this way, we could answer the question using the method we used at school', but the problem with the method at school is that it's just a method which works in the cases to answer the questions at A-Level'. It probably doesn't generalise properly and that's not the correct way of looking at situations.'

Another lecturer, who taught first-year students, expressed a similar opinion.

Mel: A-Level is very methods based. So they learn a method and then they apply it to lots of different examples. And they don't worry about where these methods come from, how they developed and why they are there. They just believe the teacher. If the teacher says, if

\footnotetext{
1 In the UK system, after compulsory education (ending at the age of 16) students may go on to study various subjects, typically 3 or 4, at Advanced Level, or 'A-Levels'. An A-Level in mathematics is often a prerequisite to study for a mathematics degree at university.
} 
you differentiate $\mathrm{x}$ cubed and (you get) three x-squared, and they'll take that on board and they'll go and differentiate functions which are made up of these standard functions and they have rules for doing that. They never worry about how these rules work, they just unquestionably take them on board and they do expect something similar at university.

These sentiments are echoed in the literature on AMT. For example, Tall \& Vinner (1981) argue that students may be so secure in their own interpretations of mathematical notions that they regard formal theory as inoperative and superfluous. Moreover, there may be instances when cognitive conflicts arise from student intuitions that have stabilised and become resistant to change (Tirosh et al., 1998). According to activity theory the 'cognitive intuitions' that cause conflicts are embedded in unexamined 'operational conditions' that fall below the level of consciousness and are all the more powerful for being unexamined and uncritically accepted (Leontiev, 1978). It is these conditions that have to be examined at breakdown moments, for instance when university practices assert they are invalid, and not 'proper' mathematics. We now turn to such a moment.

\subsection{Vignette: tutorials, contradictions and breakdown}

Robert, a first-year lecturer, and the students of his tutorial discussed a question from the problem sheet: 'To find the inverse function of $f: R \rightarrow R, f(x)=2 x+3$ '. Several students had answered this in a way that Robert indicated '[W]as not wrong, but likely to cause problems due to its imprecision'. He explained that the students had rearranged the formula $y=2 x+3$ to get $x=1 / 2(y-3)$, then rewritten this by exchanging the $x$ and the $y$ to arrive at the 'inverse' $y$ $=f(x)=1 / 2(x-3)$.

This is a correct but arguably an incomplete answer, as the domain and co-domain are left implicit. In fact both are the set of real numbers ' $R$ ', and so for the inverse function too, as $\mathrm{f}$ is in this case a bijection from $\mathrm{R}$ to $\mathrm{R}$. It is hardly surprising that the students might leave this as implicit, even if they had perhaps thought it was important. Right or wrong, why is this method such a powerful attractor for the students? At school, as one can see in various texts, a function is described as a rule mapping $\mathrm{x}$-values to $\mathrm{y}$-values, usually represented horizontally and vertically as real number lines in a graph. Thus, typical tasks/questions might ask students to sketch a graph and its image after a transformation, e.g. noting the relationship between graphs of $f(x+3)$ and $f(x-3)$.

Robert had selected this particular example to discuss with his students in the tutorial as he had marked their work beforehand and, in his own words, was 'gob-smacked' at the students' lack of understanding and by the procedural approach they took to resolve the problem. He, therefore, used the tutorial as an opportunity to make explicit to his students the need for complete writing of the mathematical proof (with explicit definition of the sets $\mathrm{X}$ and $\mathrm{Y}$ involved). Robert wrote on the board how he would prove $\mathrm{f}$ is a bijection, starting with the definition of an inverse function in which the domain and co-domain are included explicitly, thus:

Definition: the inverse function of $\mathrm{f}: \mathrm{X} \rightarrow \mathrm{Y}$ [that is, a function that maps any $\mathrm{x}$ in $\mathrm{X}$ to a single value $y$ in $Y$ given by a rule $y=f(x)]$ is a function $g$ that maps a value $y$ in $Y$ to a single value $\mathrm{x}$ in $\mathrm{X}$, (i.e. $\mathrm{g}(\mathrm{y})=\mathrm{x}$ ) such that $\mathrm{g} f(\mathrm{x})=\mathrm{x}$, for all $\mathrm{x}$ in $\mathrm{X}$.

He began to work through the solution but was interrupted by a student, Ben, who said he had obtained the right answer in his own way, and explained what he had done. Robert responded 'It is not wrong but why exchange the values $\mathrm{x}$ and $\mathrm{y}$ ?', which he claimed was likely to lead 
to confusion of the domain and co-domain. Robert encouraged Ben to illustrate the reasoning behind his answer on the board. Indeed, most of the class seemed to agree: 'That's the way we were taught at A-Level!'

Ben then chose to exemplify his approach using exponential functions from a later worksheet question: he argued that the expression $\mathrm{y}=\exp (\mathrm{x})$ was the same as $\mathrm{x}=\log (\mathrm{y})$, and that switching $\mathrm{x}$ and $\mathrm{y}$ was required to obtain the inverse function $\mathrm{y}=\log (\mathrm{x})$. Implicitly, one assumes the graph of $y=\exp (x)$ is the same as that of $x=\log (y)$, and therefore does not represent the inverse. However, Robert noted, 'Oh yes it might be, if you consider the graph as a representation of the function mapping $y$ to $x$ '. The notion that the same graph represented two inverse functions appeared to counter how the students were taught at school.

In Robert's tutorial, the students believed $\exp (\mathrm{x})$ and $\log (\mathrm{x})$ to be the inverse functions, whereas Robert pointed out that these expressions are not functions, but values. Students would have been introduced to the idea that the graphs of $\mathrm{f}$ and its inverse $\mathrm{g}$ would be reflections/images of each other in the line $y=x$. The suggestion that one graph can represent two functions ( $\mathrm{y}$ as a function of $\mathrm{x}$ and its inverse $\mathrm{x}$ as a function of $\mathrm{y}$ ) clearly contradicts the practice taught in school and explains the cognitive conflict here revealed in the tutorial dialogue.

Activity systems are multi-voiced and this multiplicity of voices can increase when activity systems interact (Engeström, 2001), which can give rise to interpersonal as well as intrapersonal conflict of a cognitive nature. Although Robert was aware of students' informal approach to learning as shaped by the school activity system, he informed us he had been unaware of the depth of the clash of values and practices between school and university involved in this example. By questioning their mathematical practices, he may have caused the students to reflect on the conflict they experienced. This created an unexpected learning opportunity. Although the students' approach was 'not wrong', Robert encouraged them to recognise the value of precision and rigour in mathematics, not fully anticipated prior to the tutorial.

Robert: Well it was very, very clear wasn't it what I learnt in that particular class. One of the things I learnt was that something has changed about the way students are taught to write functions at A-Level and their inverses and I damn well better understand what that is, and why it is... When I'm doing this class next year I will be very much more prepared and alerted.

Robert's session stood out from the other tutorials observed. Even Robert said that it deviated from the typical tutorial, which often resembled 'feedback' sessions. By contrast, Robert's tutorial seemed to us to achieve its intended purpose, i.e. to have an open dialogue about the learning material based on his prior assessment of some of the students' work.

\section{Findings: Contradictions within the university activity system}

These relatively small group tutorials had been designed to support students in first-year transition by offering a more interactive dialogue, as one lecturer Mel told us: 'You can get these ideas over and can find out if they've understood it. You can ask them questions. You can find out where their misunderstandings are and you can sort of fill in the gaps... you will never be able to do that in a lecture.' 
However, getting students to participate was not always easy. Robert noted how 'in a class of ten or eleven they feel threatened that they may get picked on - I've got their written work to see that they are not doing very well, and they're apprehensive, [they are] cagey about admitting that they don't understand anything. They'll just sit there and be totally lost'. The challenges concerning the division of labour in the form of low levels of student participation often made tutorials appear stilted; students were positioned 'purely as recipients of the information', as Robert indicated. Of Ben, the student who spoke up in his tutorial, Robert said: 'he, unlike some of them, was willing to speak up and to listen, and I bet he's got a better understanding now of what was happening. Many of the others in the class I've no idea'.

The tutorial situation was difficult for some lecturers who were mainly used to lecturing, telling us that they were torn between getting students through the course and engaging them with the material at a relational level. Students also reported having difficulties: 'That was really annoying when we did turn up and when we had a question that when we did get to the problem [the tutor] didn't really answer the question as to why. He'd just like do it himself and then expect us just to know what he's done and why he's done it.'

Lecturers were aware of issues such as lack of sufficient time to present all the worksheet solutions as well as develop general understandings. Lecturer discourse indicated a lack of agency in the face of the rules governing the undergraduate curriculum and assessment structure generally: as one lecturer said: 'We are not free in teaching. Many syllabuses are dominated by, well students have to survive the exams. There's this gun that I have in my back which says, 'you cannot explain what your topic is actually about. You have to prepare it in a way that is examinable', to bring them in the situation so that at least they have some tools to pass exams, so that most of the students pass as required'. Thus labour time is at the root of the contradiction: primary contradictions relate to the essential conflict between exchange (as determined by labour time) and use value (Engeström, 1987).

It appears that the very same characteristic of school learning that is often blamed for students' cognitive deficits applies equally to university: procedural practices continue to flourish at the expense of conceptual development. One lecturer, Gert, commented: 'When I came here two years ago at the beginning I was very outraged. If I would teach what I would like to, they wouldn't understand it, or they wouldn't like to understand it, and I don't blame the students, it's just the university does not allow the students to understand.'

Gert's discourse suggests how the contradictions within the university activity system can mediate student motivation and understanding, or lack thereof, regarding advanced mathematics. His discourse also illustrates how opposing forces within activity systems manifest in tensions in individual subjectivity. These tensions in subjectivity caused by contradictions are also observed in the discourse of students. As described earlier, when students transition to the university activity system, they experience changes in the social and material conditions that mediate their experiences with mathematics. These changes not only give rise to a conflict to student cognition but can also cause students to question their own mathematical identities. One first year student, Mark, claimed he chose to study mathematics at university as he thought 'just stick with what you know'. However, the mathematics he experienced at university came as a 'shock'.

Mark: It was a shock to the system that people, like, can't understand why they only got $50-60 \%$ in the exams, 'cos they're used to getting $90-100$ 's at A-Level. It was a sort of, 
'hold on, we understood everything at A-Level, why are we not understanding this straight away'... I probably don't like it for that reason, because it didn't click... They see something like a proof and it scares them, they don't try and just think about it. I was one of those. I guess I still am.

\begin{abstract}
We asked Mark if he considered himself to be a mathematician and he replied, 'I thought I did before university, I'm not so sure now'. We thus observe from Mark, and overall in this paper, how activity systems, together with their inherent tensions between and within them, are embodied and can mediate students' learning of advanced mathematics at university and even challenge their identification with the subject.
\end{abstract}

\title{
7. Conclusion
}

The main point of this paper has been to argue that student difficulty with advanced mathematics can be understood as formed by a series of contradictions between the school and university mathematical activity systems, as well as those located within the latter. This helps to direct our attention from the individual student in understanding their difficulty with advanced mathematics to the activity systems that mediate their activity. The implication of this is important. Analysing the components that make up activity systems can facilitate critical reflection on the broader sociocultural environment, which forms a complex web of forces, some of which opposing, shaping individual disposition, motives, and engagement with advanced mathematics. This can help us shift 'blame' from the student (paraphrasing Gert) and apply a critical stance to the activity systems themselves, and how it is these activity systems which shape student (dis)engagement with mathematics.

Activity theory offers several other advantages including that it helps to socioculturally situate the cognitive conflict students can experience with AMT at university. Activity theory frames consciousness as being stretched beyond the head of the individual and formed in historically developed and tool-mediated practice with others. Thus, in order to understand the development of student mathematical thinking from the perspective of activity theory, we need to look at all components of activity systems such as the object, tools, rules, community, and division of labour, and the contradictions within and between them. These contradictions, as well as those between different activity systems, can cause conflict to student cognition and even identity.

The transition to university mathematics has been observed to cause student difficulties where different learning demands are placed on them (Pritchard, 2015; Williams, 2015) and where their relationship to mathematics as shaped by experiences at A-Level are challenged when they encounter mathematics at university (Lawson, 2015). This difficulty that students can encounter with the general transition to university and with university level mathematics can be conceptualised as one associated with identity.

When individuals transition from one activity system to another, this can result in a tension in subjectivity and thus identity. We observe this in Mark's discourse, where the advanced mathematics encountered in the university activity system resembled a different way of knowing mathematics and being a mathematician, which made him question his identity of being a mathematician. The contradictions found in activity systems and how these can be manifest in a conflict of identity is also witnessed in relation to Gert; he felt torn between various motives and alluded to a lack of agency in relation to the contradictions that shaped the learning and teaching environment within the university activity system. This conflict to 
identity as a result of contradictions between and within activity systems and how this is tied to student cognition is explored further elsewhere (Jooganah, 2015).

Another key advantage with activity theory is the focus it offers on the systems that might be developed to support students' learning of advanced mathematics. On entering the university system students are likely to be equipped with tools that may be no longer fit for purpose in advanced mathematics. Additionally, the kind of activity that might help students manage this is not always supported within the university system due to internal contradictions there, e.g. the resource constraint makes small group tutorials institutionally unattractive compared to large lectures.

Barab et al., (2002) argue that contradictions in activity systems cannot be controlled from the outside or through some form of written guidance, but need to be managed in situ, as each context is different. They suggest that reading the rich descriptions and struggles those in education encounter can provide insight others can use in addressing the contradictions affecting their own pedagogic practice. In the case illustrated in this paper, we found some merit in the creation of a breakdown moment in tutorial dialogue that exposed a core contradiction in the practice of mathematical functions between school and advanced mathematics at university, and from which it seemed the students and lecturer had an opportunity to confront the associated cognitive conflict and develop conceptually (if not procedurally). Such breakdowns can be important as student understanding of concepts like functions can be considered as boundary objects (Star \& Griesemer, 1989). They have contested meanings within the school and university activity systems and such differences may be implicit such that lecturers and even students may not necessarily be aware of them. It could be argued that creating breakdown moments can aid in the creation of communities of inquiry where there is critical alignment with participants questioning the practices in which they engage. This, as Biza et al., (2014) argue, can lead to new forms of practice that can effectively support students' learning.

\section{REFERENCES}

Barab, S. A., Barnett, M., Yamagata-Lynch, L., Squire, K., \& Keating, T. (2002). Using activity theory to understand the systemic tensions characterizing a technology-rich introductory astronomy course. Mind, Culture, and Activity, 9, 76-108.

BARNARD, T. (2002) Reducing mathematics to human size. Research in Mathematics Education, 4, 115-126.

BiZA, I., JAWORSKI, B., \& HEMMI, K. (2014) Communities in university mathematics. Research in Mathematics Education, 16, 161-176.

DREYFUS, T. (1991) Advanced mathematical thinking processes. Advanced Mathematical Thinking (D. TALL ed). Dordrecht: Kluwer Academic Publishers, pp. 25-41.

DUVAL, R. (2006) A cognitive analysis of problems of comprehension in a learning of mathematics. Educational Studies in Mathematics, 61, 103-131.

EDWARDS, B. S. \& WARD, M. B. (2004) Surprises from mathematics education research: Student (mis)use of mathematical definitions. The American Mathematical Monthly, 111, 411-424.

EDWARDS, B. S., E. DuBINSKY, \& MCDONALD. M. A. (2005) Advanced mathematical thinking. Mathematical Thinking and Learning, 7, 15-25. ENGESTRÖM, R. (1987) Learning by expanding: An activity-theoretical approach to developmental research. Helsinki: Orienta-Konsultit. 
ENGESTRÖM, Y. (1999) Innovative learning in work teams: Analysing cycles of knowledge creation in practice. Perspectives on activity theory (Y. ENGESTRÖM, R. MIETTINEN \& R-L. PUNAMÄKI eds). Cambridge: Cambridge University Press, pp. 377-404.

ENGESTRÖM, R. (2001) Expansive learning at work: Toward an activity theoretical reconceptualization. Journal of Education and Work, 14, 133-156.

ENGESTRÖM, Y. \& SANNINO, A. (2010) Studies of expansive learning: Foundations, findings and future challenges. Educational Research Review, 5, 1-24.

Goodchild, S., Fuglestad, A. B., \& JAWORSKI, B. (2013) Critical alignment in inquirybased practice in developing mathematics teaching. Educational Studies in Mathematics, 84, 393-412.

Gray, E., Pinto, M., PitTA, D. \& TAll, D. (1999) Knowledge construction and diverging thinking in elementary and advanced mathematics. Educational Studies in Mathematics, 38, 111-133.

HAREL, G. \& KAPUT, J. (1991) The role of conceptual entities and their symbols in building advanced mathematical concepts. Advanced Mathematical Thinking (D. TALL ed). Dordrecht: Kluwer Academic Publishers, pp. 82-94.

HEMMi, K. (2008) Students' encounter with proof: The condition of transparency. ZDM Mathematics Education, 40, 413-426.

JONASSEN, D. H. \& ROHRER-MURPHY, L. (1999) Activity theory as a framework for designing constructivist learning environments. Educational Technology Research and Development, 47, 62-79.

JOOGANAH, K. (2015) Undergraduate students' learning experiences with advanced mathematics: A focus on contradictions and student identity. Ph.D. Thesis, The University of Manchester, UK.

KUUTTI, K. (1996) Activity theory as a potential framework for human-computer interaction research. Context and consciousness: Activity theory and human-computer interaction (B. A. NARDI ed). Cambridge, MA: MIT Press, pp. 17-44.

LAVE, J. \& WENGER, E. (1991) Situated learning: Legitimate peripheral participation. Cambridge: Cambridge University Press.

LAWsOn, D. (2015) Mathematics support at the transition university. Transitions in Undergraduate Mathematics Education (M. Grove, T. CrofT, J. KYLE \& D. LAWSON eds). Birmingham: The Higher Education Academy, University of Birmingham, pp. $39-56$. LeOntIEV, A. N. (1978) Activity, consciousness, and personality. Hillsdale: Prentice Hall. LEONTIEV, A. N. (1981) The problem of activity in psychology. The concept of activity in Soviet psychology (J. V. WERTSCH ed). New York: Sharpe, Inc., pp. $37-71$.

MAHIR, N. (2009) Conceptual and procedural performance of undergraduate students in integration. International Journal of Mathematics Education in Science and Technology, 40, 201-211.

MeJíA-RAmos, J. P. \& INGLIS, M. (2011) Semantic contamination and mathematical proof: Can a non-proof prove? Journal of Mathematical Behavior, 30, 19-29.

Moore, R. C. (1994) Making the transition to formal proof. Educational Studies in Mathematics, 27, 249-266.

NARDI, B. A. (1996) Studying context: A comparison of activity theory, situated action models, and distributed cognition. Context and consciousness: Activity theory and humancomputer interaction (B. A. NARDI ed). Cambridge, MA: MIT Press, pp. 69-102.

OUVRIER-BUFFET, C. (2011) A mathematical experience involving defining processes: Inaction definitions and zero-definitions. Educational Studies in Mathematics, 76, 165-182. Pedemonte, B. \& REID, D. (2011) The role of abduction in proving processes. Educational Studies in Mathematics, 76, 281-303. 
PerRenet, J., \& TACONIS, R. (2009) Mathematical enculturation from the students' perspective: Shifts in problem-solving beliefs and behaviour during the bachelor programme. Educational Studies in Mathematics, 71, 181-198.

PRITCHARD, D. (2015) Lectures and transition: from bottles to bonfires? Transitions in Undergraduate Mathematics Education (M. GROVE, T. CROFT, J. KYLE \& D. LAWSON eds). Birmingham: The Higher Education Academy, University of Birmingham, pp. 57-69. SANNinO, A., DANIELS, H. \& GUTIERREZ, K. D. (2009) Learning and expanding with activity theory. New York: Cambridge University Press.

SELDEN, A. \& SELDEN, J. (2003) Validations of proofs considered as texts: Can undergraduates tell whether an argument proves a theorem? Journal for Research in Mathematics Education, 34, 4-36.

SFARD, A. (1998) On two metaphors for learning and the dangers of choosing just one. Educational Researcher, 27, 4-13.

Solomon, Y. (2006) Deficit or difference? The role of students' epistemologies of mathematics in their interactions with proof. Educational Studies in Mathematics, 61, 373393.

STAR, S. L. \& GRIESEMER, J. R. (1989) Institutional ecology, 'translations,' and boundary objects: Amateurs and professionals in Berkeley's museum of vertebrate zoology. Social Studies of Science, 19, 387-420.

TALL, D. (1991) Advanced mathematical thinking. Dordrecht: Kluwer Academic Publishers. TALL, D. (2008) The transition to formal thinking in mathematics. Mathematics Education Research Journal, 20, 5-24.

TALL, D. \& VINNER, S. (1981) Concept image and concept definition in mathematics with particular reference to limits and continuity. Educational Studies in Mathematics, 12, 151169.

ThOMAS, M. O. J. \& STEWART, S. (2011) Eigenvalues and eigenvectors: Embodied, symbolic and formal thinking. Mathematics Education Research Journal, 23, 275-296.

Tirosh, D., Stavy, R. \& CoHEN, S. (1998) Cognitive conflict and intuitive rules.

International Journal of Mathematics Education in Science and Technology, 20, 1257-1269.

TrANSMATHS. (n.d.). About Transmaths. Retrieved September 27, 2015, from

http://transmaths.org/.

VYGOTSKY, L. S. (1978). Mind in society: The development of higher psychological processes. Cambridge, Mass: Harvard University Press.

VYGOTSKY, L. S. (1981) The instrumental method in psychology. The concept of activity in Soviet psychology (J. V. WERTSCH ed). New York: Sharpe, Inc., pp. 134-143.

WEBER, K. (2010) Mathematics majors' perceptions of conviction, validity, and proof. Mathematical Thinking and Learning, 12, 306-336.

Wenger, E. (1998) Communities of practice. Cambridge: Cambridge University Press. WILLIAMS, J. (2012). Use and exchange value in mathematics education: Contemporary CHAT meets Bourdieu's sociology. Educational Studies in Mathematics, 80, 57-72. Williams, J. (2015) Mathematics education and the transition to Higher Education. Transitions in Undergraduate Mathematics Education (M. GROVE, T. CROFT, J. KYLE \& D. LAWSON eds). Birmingham: The Higher Education Academy, University of Birmingham, pp. 25-37.

Williams, J. S., WAKe, G. D. \& Boreham, N. C. (2001) School or college mathematics and workplace practice: An activity theory perspective. Research in Mathematics Education, 3, 69-83.

YANG, K. L. (2011) Structures of cognitive and metacognitive reading strategy use for reading comprehension of geometry proof. Educational Studies in Mathematics, 1-2. 